\title{
FACTORS AFFECTING AND ANATOMICAL ASPECTS OF IN VITRO SHOOT REGENERATION OF FLAX (Linum usitatissimum L.)
}

(Received: 17.12.2009)

\author{
By \\ A. A. Mohamed, A.Z. Sabh and Z. K.T. Shaarawy \\ Department of Agricultural Botany, Faculty of Agriculture, Cairo University, Giza, Egypt.
}

\begin{abstract}
Direct shoot regeneration of two flax cultivars; Blanka (a fiber cultivar) and Giza 8 (a dual purpose cultivar) was conducted in vitro using different explants from the seedling (hypocotyl, cotyledon and root). Factors affecting as well as stages and capacity of direct shoot regeneration and anatomical features of in vitro induced shoots comparing with in vivo shoots were studied. The most remarkable outcomes proved that the used culture medium is the key factor that affecting the shoot regeneration when combined with any other factor (explant type, explant age and genotype). Hypocotyl explant proved to elevate shoot regeneration percentages that varied between 33 to $95 \%$. Three days aged explant bear out the highest percentage of shoot regeneration as compared with explant aged 7 days. The most medium was MS basel medium supplemented with $0.25 \mathrm{mg} / \mathrm{l} \mathrm{NAA}+0.50 \mathrm{mg} / \mathrm{l} \mathrm{BA}$. Inductive flax cv. Blanka showed a higher shoot regeneration percentage as compared with the other genotype flax cv. Giza8. Bud formation was initiated on the surface of the flax seedling hypcotyl as small projection, this projection showed a heavy wrinkled and waved sculpture, later it developed into normal shoot bud with mersitematic dome. The anatomical features of in vivo and in vitro stems and leaves were inversely distinctive as the in vitro stems were wider and maintained thicker epidermal cells as well as thicker cortex and pith whereas having lesser amount of supportive and vascular tissues. Comparing with in vivo leaves, the in vitro leaves were thiner with poor differentiated epidermal, mesophyll and vascular tissues. The in vitro leaves showed bigger and denser stomata area in both leaf surfaces.
\end{abstract}

Key words: adventitious bud - Linum usitatissimum -shoot regeneration

Abbreviations: BA: Benzyl adenine, 2, 4-D: Dichlorophenoxy acetic acid , NAA: Naphthalene acetic acid

\section{INTRODUCTION}

Flax (Linum usitatissimum L.) is one of the most earliest domestic and cultivated plant species. It is an important source of natural fibers for textile industries and oil for the production of paints, varnishes, inks, linoleum and pharamaceaticals. (Green and Marshall, 1984, and Belonogova and Raldugina, 2006). Moreover it has the potential of meeting edible oil and protein deficiency (Green, 1986). Flax improvement has not been developed at the same rate as in other crops. Biotechnology and genetic engineering can lead to speed up flax breeding and providing incorporation of valuable and desirable traits as salinity tolerance (Mc Hughen and Schwartz, 1984) and resistance to Fusarium oxysporum (Rutkowska et al., 2003). Tissue culture of flax has been carried out for more than 30 years. In vitro flax regeneration through direct organogenesis is considered as the most valuable method as having higher regeneration percentage and lower number of somaclonal variants in comparison with regeneration through embryogenesis (Cristina et al.,1997; and Dedicova et al., 2000) or indirect organogenesis (Bretagne et al., 1994). For shoot regeneration, various flax explants were used; hypocotyl (Lane, 1979, Mustafa and Murat, 2002 and Blinstrubiene et al., 2004), Cotyledon (Belonogova and Raldugina, 2006), root (Cristina et al., 1997), anther (Burbulis et al., 2007), ovary (Bartosova , 2006), protoplast (Ling and Binding, 2006), however, hypocotyl segments proved to be highly efficient (Friedt, 1990). Other factors as genotype, age of donor plant, medium composition, and stress also affected the regeneration process. Blinstrubiene et al. (2004) reported that flax shoot regeneration largely depends on the genotype, while (Cristina, et al., 1997), stated a genotype- independent procedure. Although flax shown to be responsive in vitro to a wide range of growth regulators including thidiazuron (Bretagne et al., 1994), naphthalene acetic acid and benzyl adenine are the most commonly used for direct shoot 
regeneration. Flax hypocotyl segments from 5 and 7 day old seedlings were cultivated in vitro for direct regeneration by Dedicova et al. (2000) and Mustafa and Murat (2002).

Direct regeneration of adventitious shoot meristems formed directly on explants in vitro is often initiated by cell division beginning in the epidermal and subepidermal layers. The initial cell division results in a mass of cells forming new meristematic centers (meristemoides), later becoming a shoot apical meristem with meristematic dome and leaf primordia (shoot bud) and finally developing into normal shoot. Regeneration in this manner is widespread occurring in monocots (e.g. Allium sativum L., Mahammad et al., 1999), dicots (e.g. Aloysia polystachya L., Brudyni et al., 2006) and conifers (e.g. spruce, Saravatiz et al., 1993) .On flax, only two reports were published ; Keiko et al. (1997) on decapitated seedlings and Dedicova et al.(2000) on hypocotyl explant .

With respect to the anatomical characteristics of the in vitro plants in comparison with in vivo plants, it is well known that the special conditions during the in vitro culture cause morphophysiological disorders of plantlets that result in poor survival during acclimatization (Hazarika, 2005) and prevent the successful use of tissue culture technique in crop improvement through genetic engineering. The leaves that develop in vitro generally lack well developed epicuticular waxes and have thin cuticle (Sutter and Langhans, 1982), they have increased number of malfunctioning small size stomata (Brainerd and Fuchigami,1981 ; Marin et al.,1988 and Johanson et al.,1992) , poor development of the photosynthetic apparatus (Prece and Sutter,1991) with no or few rows of palisade cells (Rosna and Noorma, 2008) with lower chloroplast number, poorly developed thylakoid staking, and low amount of chlorophyll and disorganized grana (Majada et al., 2002) . Moreover, leaves and stems of in vitro shoots are characterized by relatively poor developed supportive and vascular tissues (Hazarika, 2005). As far as the authors are aware, the anatomical characteristics of flax plantlets grown in vitro had not been studied.

The aim of this research was to: 1- elucidate the effect of genotype, explant type, explant age and culture medium on the in vitro direct shoot regeneration of flax and 2- study the anatomical aspects of the in vitro shoots in comparison with the in vivo plants.

\section{MATERIALS AND METHODS}

Seeds of two flax cultivars namely. Blanka (fiber type) and Giza 8 (dual purpose type) were surface sterilized by $70 \%$ ethanol for $2 \mathrm{~min}$ followed by immersing in $80 \%$ Clorox for $20 \mathrm{~min}$ and then rinsed four times each of $5 \mathrm{~min}$ in sterile distilled water. Seeds were germinated on $0.7 \%$ agar full strength MS medium (Murshige and Skoog ,1962) supplemented with 3\% sucrose and without growth regulators. After 3 and 7 days from germination the hypocotyl, cotyledon, root explants were placed on shoot regeneration media consisted of MS basal medium enriched with 3\% sucrose and $0.2 \%$ gelrite. For induction of direct shoot regeneration various combinations of growth regulators were added $0.25 \mathrm{mg} / \mathrm{l} \mathrm{NAA} \mathrm{+}$ $0.5 \mathrm{mg} / \mathrm{l} \mathrm{BA}, 2.0 \mathrm{mg} / \mathrm{l} \mathrm{NAA}+2.0 \mathrm{mg} / \mathrm{l} \mathrm{Kin}, 0.25$ $\mathrm{mg} / \mathrm{l}$ 2,4-D+2.0mg/l Kin, $0.25 \mathrm{mg} / 1$ 2,4-D+0.50 $\mathrm{mg} / \mathrm{l} \mathrm{BA}$ and the medium $\mathrm{pH}$ was adjusted to 5.7 - 5.8. The culture medium was sterilized by autoclaving at $121^{\circ} \mathrm{C}$ for $20 \mathrm{~min}$. and incubated under controlled conditions of temperature $24 \pm$ $2^{\circ} \mathrm{C}$ with 16 hours photoperiod under cool white fluorescent light. Intensity of illumination was 3000 Lux. At the end of the culture (5 weeks later) shoot regeneration percentage was estimated for scanning electron microscopy. Samples were fixed in $4 \%$ glutaraldehyde in 0.1 phosphate buffer (pH7.2) overnight at $4^{\circ} \mathrm{C}$ and then dehydrated through graded ethanol series and critical-point dried in liquid carbon dioxide. Specimens were mounted on stubs, sputter coated with gold, and examined with a scanning electron microscope (model JSM-T220; Jeol Ltd.). For the anatomical studies semi thin sections were prepared through cutting at $1 \mathrm{~m} \mu$ using the ultramicrotome model EM-UC6. Sections were stained with Toludine blue mounted and examined by light microscope.

\section{RESULTS AND DISCUSSION}

\subsection{Factors affecting direct regeneration}

Shoot regeneration capacity was influenced by many factors; i.e., explant type, explant age, genotype and medium composition. The statiscal analysis showed that the interactions between these factors significantly affected the average percentages of shoot regeneration. So, the optimal combinations that produced high regeneration percentage, regardless the effects of the other factors, will be thrash out in this study.

The used culture medium was the key factor that affecting the shoot regeneration when combined with any other factor (explant type, explant age and genotype). The over all shoot regeneration percentages regardless the effects of 
other factors were, 17,20, 49 and $54 \%$ for medium supplemented with 2,4-D (0.25 mg/l) + BA (0.5 $\mathrm{mg} / \mathrm{l})+\mathrm{BA}(0.5 \mathrm{mg} / \mathrm{l})$, respectively (Fig. 1, A). The interaction between the used medium and the explant type showed different response. It is clear that, in both flax cultivars the hypocotyl was the best explant for the induction of direct shoot regeneration followed by cotyledon and root explant. Data illustrated in (Fig. 1,B) show that, the average shoot regeneration percentages due to explant type, calculated regardless of the other factors under study, were 82, 54 and $9 \%$ for the three studied explant hypocotyl, cotyledon and root, respectively. Moreover, hypocotyl explant combined with the four tested growth regulator combinations proved to induce high shoot regeneration percentages that varied between 33 to $95 \%$. The highest shoot regeneration percentage $95 \%$ was recorded with MS medium supplemented with NAA $(0.25 \mathrm{mg} / \mathrm{l})+\mathrm{BA}(0.5$ $\mathrm{mg} / \mathrm{l})$. While the lowest recorded percentage $0.0 \%$ was noted with root explant incubated with the medium supplemented with NAA $(2.0 \mathrm{mg} / \mathrm{l})+\mathrm{Kin}$ $(2.0 \mathrm{mg} / \mathrm{l})$. However, cotyledon explants gave intermediate direct regeneration percentages.

The shoot regeneration percentages as affected by explant age; 3 or 7 days combined with medium composition are shown in (Fig 1, C). Generally, 3 days aged explant proved to maintain the highest shoot regeneration as compared with explant aged 7 days. The average recorded shoot regeneration percentages using 3 days aged explant, regardless the other factors under study, were $72 \%$ compared with $36 \%$ for 7 days aged explant, (Fig 1, C). The interaction between the explant age and the used medium showed that, within each medium, shoot regenaration percentages were not greatly affected by the explant age. Where, the average percentage differences between explants aged 3 and 7 days within each used medium, ranged from $1 \%$ in case of NAA $(0.25 \mathrm{mg} / \mathrm{l})+\mathrm{BA}(0.5 \mathrm{mg} / \mathrm{l})$ to $16 \%$ in case of NAA $(0.25 \mathrm{mg} / \mathrm{l})+\mathrm{BA}(0.5 \mathrm{mg} / \mathrm{l})$. In addition, the highest recorded percentages were regarded for explants, cultured on MS medium supplemented with NAA $(0.25 \mathrm{mg} / \mathrm{l})+$ BA $(0.5$ $\mathrm{mg} / \mathrm{l})$, were 53 and $54 \%$ for explant aged 3 and 7 days, respectively. While, the lowest recorded percentages were 17 and $10 \%$ for explants aged 3 and 7 days and cultured on MS medium supplemented with 2, 4-D $(0.25 \mathrm{mg} / \mathrm{l})+\mathrm{Kin}$ (2.0mg/l).

Regarding the genotype effects on direct regeneration, the two used genotypes were different regarding shoot regeneration capacities. Generally, the over all shoot regeneration percentage of Blanka regardless of the other $\mathrm{mg} / \mathrm{l}), 2,4-\mathrm{D}(0.25 \mathrm{mg} / \mathrm{l})+\mathrm{Kin}(2.0 \mathrm{mg} / \mathrm{l})$, NAA $(2.0 \mathrm{mg} / \mathrm{l})+\mathrm{Kin}(2.0 \mathrm{mg} / \mathrm{l})$ and NAA ( 0.25 investigated factors was $39 \%$ comparing with $33 \%$. For the other genotype Giza 8. The interaction between genotype and the used medium was differed significantly. Blank showed $64 \%$ which was the highest shoot regeneration percentage with the medium supplemented with NAA $(0.25 \mathrm{mg} / \mathrm{l})+\mathrm{BA}(0.5 \mathrm{mg} / \mathrm{l})$. While it showed $10 \%$ shoot regeneration percentage with the medium supplemented with 2,4 -D $(0.25 \mathrm{mg} / \mathrm{l})$ $+\operatorname{Kin}(2.0 \mathrm{mg} / \mathrm{l})$. The same trend with relatively lower percentages was obtained with the other genotype Giza 8.

From the above mentioned results it is clear that shoot regeneration capacity was influenced by the used culture media. This was early reported by Tejklova (1992) and Cointry et al. (1993). They reported that flax direct shoot regeneration explants were cultured in vitro on MS medium supplemented with $0.01,0.1,1.00$ or $3.0 \mathrm{mg} / \mathrm{l}$ IAA, NAA or 2, 4-D alone or in combination with the same concentrations of [BA]. The optimal combination of growth substances for bud regeneration on shoot segments was $1.0 \mathrm{mg} / \mathrm{l} \mathrm{BA}$.

The type of the explant also, affects the shoot regeneration capacity. This was early reported by Netherland et al. (1988) and Zhan et al. (1989). They mentioned that hypocotyl explant seemed to be the best explant source for bud regeneration, followed by roots. Moreover, the present outcomes revealed that explant age and the They mentioned that hypocotyl explant seemed to be the best explant source for bud regeneration, followed by roots. Moreover, the present outcomes revealed that explant age and the used genotype affect shoot regeneration. This is confirmed by Cointry et al. (1993), Dedicova et al. (2000) and Blinstrubiene et al. (2004).

\subsection{Shoot bud regeneration on hypocotyl explant}

The adventitious bud formation was traced using electron microscopy. It is evident that bud formation was initiated without distinct orientation on the surface of the flax seedling hypocotyl as small projection from the hypocotyls surface. This projection showed a heavy wrinkled and waved waxy sculpture (Fig2, a). From the top view of the developed bud a minute differentiated leaf primordia could be seen (Fig 2, b). The adventitious bud elongated and formed the central shoot axis (Fig 2, c). Finally, the adventitious bud showed a typical dicotyledonous shoot tip flanked by leaf pirmodia (Fig 2, d). The developmental histological study of adventitious shoot bud formation on decapitated flax seedling was reported by Marchuk and Raju (1978) and Keiko 

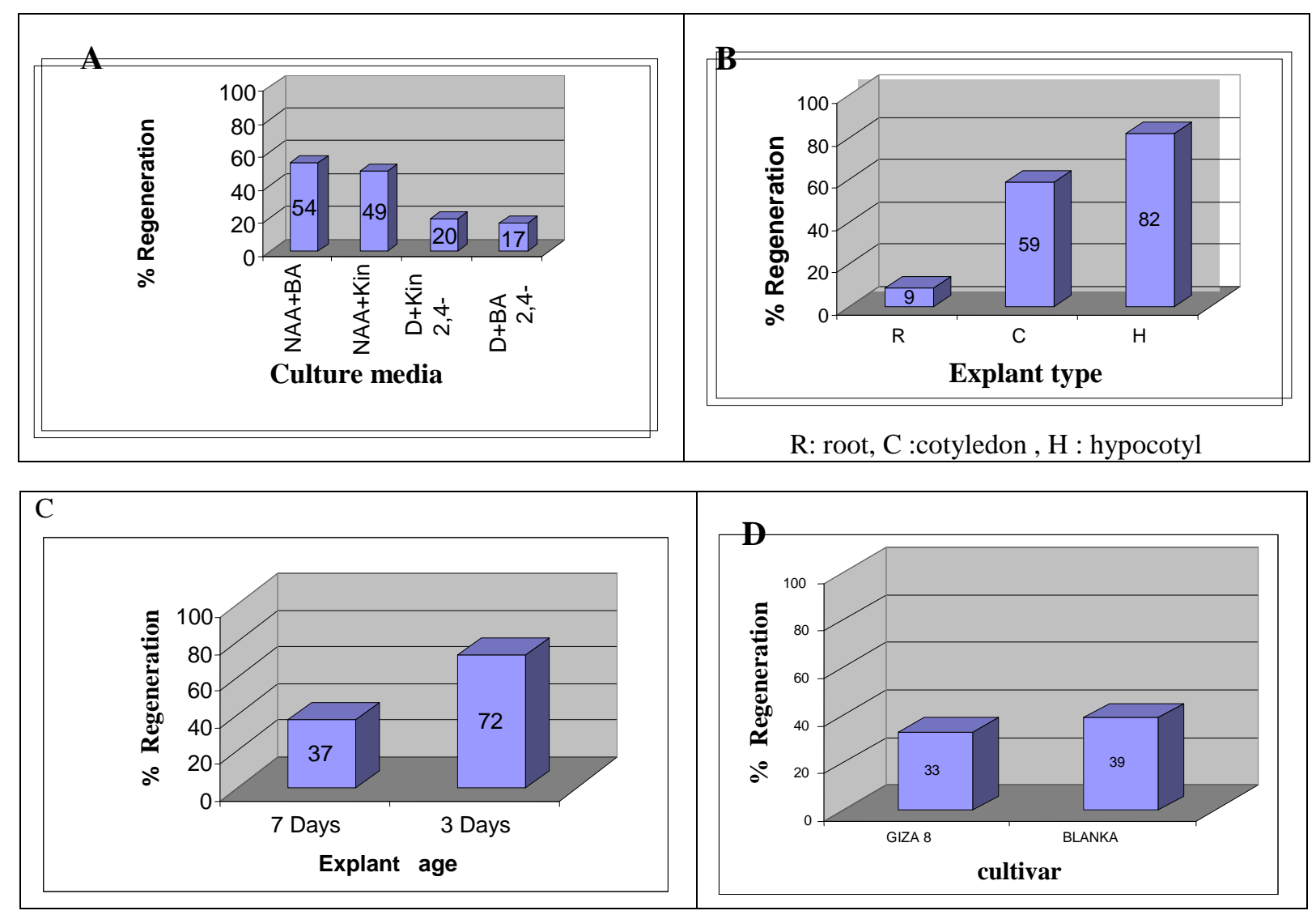

Fig. (1): The effects of culture medium, explant type, explant age and the genotype on direct shoot regeneration percentages of flax.
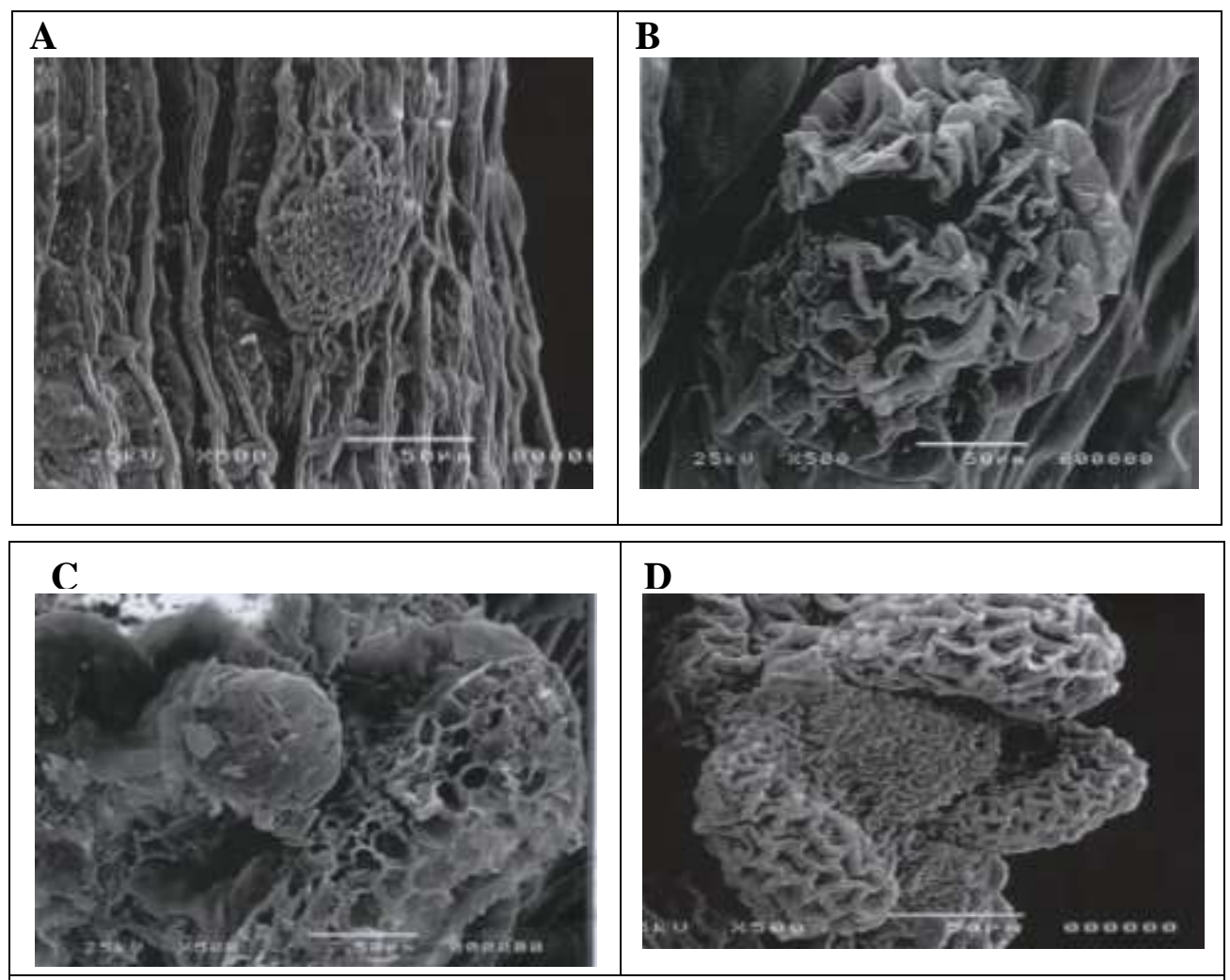

Fig .(2): Developmental stages of adventitious shoot bud formation on flax hypocotyl as seen by electron microscope. 
et al. (1997).

3.3. Comparative anatomy of in vitro and in vivo developed shoots

\subsubsection{Stem anatomical structure}

The anatomical structure of the stems, either induced in vitro or grown in vivo was explored through the transverse sections in the $2^{\text {nd }}$ internode of the stem. Full microscopic measurements and counts are presented in Table (1) and (Fig. 3).

It is noticeable that the stem layout is round in outline and maintained the typical dicotyledonous stem features. One of the major differences between the in vivo and in vitro stems is the average stem diameter. Generally, in vivo stems epidermis thicknesses for Giza were 819.9 and $17.4 \mu$. indcating that, in vitro plant stems showed thicker epidermis as compared with in vivo stem, (Tabel 1 ) and Fig 3).

The cortex of the in vivo stems was composed of two main regions; the hypodermis (outer region) with firm consistent angular collenchyma cells and the inner region showed typically thin walled parenchyma cells. So, the in vivo stems showed well developed hypodermis collenchyma cells. The average cortex thicknesses were 198.5 and $221.0 \mu$ for the in vitro stem of Blanka and Giza 8, respectively . The outer cortex region showed five rows of normal angular collenchyma cells.

Table (1) : Average measurements $(\mu)$ and counts of certain microscopical features in transverse sections of the in vitro and in vivo stems of two flax cultivars Blanka and Giza 8 .

\begin{tabular}{|l|c|c|c|c|}
\hline \multirow{2}{*}{ Cultivars } & \multicolumn{2}{c|}{ Blanka } & \multicolumn{2}{c|}{ Giza 8 } \\
\cline { 2 - 5 } Characters & In vitro & In vivo & In vitro & In vivo \\
\hline Stem diameter & 997.0 & 816.0 & 1034.0 & 907.0 \\
\hline Epidermis thickness & 20.7 & 16.8 & 19.9 & 17.4 \\
\hline Cortex thickness & 198.5 & 164.2 & 221.0 & 183.2 \\
\hline Diameter of cortical cells & 46.6 & 38.2 & 40.3 & 36.1 \\
\hline Number of cortical layers & 5.0 & 7.0 & 5.0 & 8.0 \\
\hline Vascular Bundles dimensions & & & & \\
$\quad$ Length & 88.9 & 109.8 & 90.1 & 103.2 \\
$\quad$ Width & 57.1 & 60.5 & 60.5 & 66.8 \\
\hline Number of xylem rows/ bundle & 5.0 & 8.0 & 6.0 & 7.0 \\
\hline Vessel diameter & 27.9 & 36.2 & 28.6 & 33.6 \\
\hline Phloem thickness & 44.9 & 58.2 & 48.4 & 51.6 \\
\hline Pith cell diameter & 73.7 & 63.0 & 76.2 & 60.8 \\
\hline Pith diameter & 532.1 & 441.8 & 496.7 & 462.3 \\
\hline
\end{tabular}

exhibited narrower stem diameter as compared with the in vitro stems. As well, stem internal structure of the two genotypes under investigation Balnka and Giza 8 showed different measurements and counts. The average increased percentages in stem diameter of the in vitro stems were 22.0 and $14.0 \%$ for Blanka and Giza 8, respectively. However, the average stem diameters of flax cv. Blanka scored, 816 and $997 \mu$ for the in vivo and in vitro stems. While, in the case of Giza 8 they were 907 and $1034 \mu$. The stem epidermis is characterized by uniform thin walled barrel shaped cells. It is evident that the epidermis of in vivo stems is covered by relatively thick waxy cuticle as compared with the in vitro stems. The anatomical features of both in vitro and in vivo stems showed no trichomes on both surfaces of the epidermis. The average thicknesses of the epidermis as shown in the transverse sections of the Blanka were 20.7 and $16.8 \mu$ for in vitro and in vivo stems, respectively. The corresponding
Furthermore, the cortex of the in vitro stems showed relatively large parenchyma cells as compared with that of in vivo stems, where the average size of cortex parenchyma cells gained 17.2 and $12.6 \%$ increase in diameter, for the two studied cultivars. The vascular tissues forming the stem stele showed discontinuous ring of fascicular and inter-fascicular cambium, differentiated to a number of different sized diffuse collateral vascular bundles. Reversely, the in vitro stems showed reduced vascular bundles as compared with those of the in vivo stems. This reduction reflected on both length and width of the vascular bundles and all tissues shared in their structure. The average dimensions (length - width) of the vascular bundles of the in vivo stems as shown in transverse section were 109.8, 60.5 and 103.2, $66.8 \mu$ for Blanka and Giza 8, respectively. The corresponding dimensions of the in vitro stems were $88.9,57.1$ and $90.1,60.5 \mu$, for the two flax 
cultivars in the same order. The reduction in vascular bundle length was mainly due to the reduction occurred in both xylem vessels diameter and number of differentiated vessels rows in the stem radial direction (Fig 3, a\&c).

The vascular bundles of the in vitro stems had compressed phloem with minute amounts of sieve elements mixed with phloem fibers which are quite undifferentiated as it showed scattered clusters of fiber cells mixed with extensive amounts of parenchyma cells. The average thicknesses of the phloem of the in vivo stems of . Blanka and Giza 8 were $58.2 \mu$ and $51.6 \mu$, and $44.9 \mu$ and $48.4 \mu$ for the in vitro respectively. Xylem vessels exhibited variable size as the average vessel diameters of the in vitro stems. The in vitro stems showed wider pith as compared were 27.9 and $28.6 \mu$ for the two studied flax cvs. Blanka and Giza 8, respectively. These values were reduced by 25.0 and $15.1 \%$ as compared with the vessels

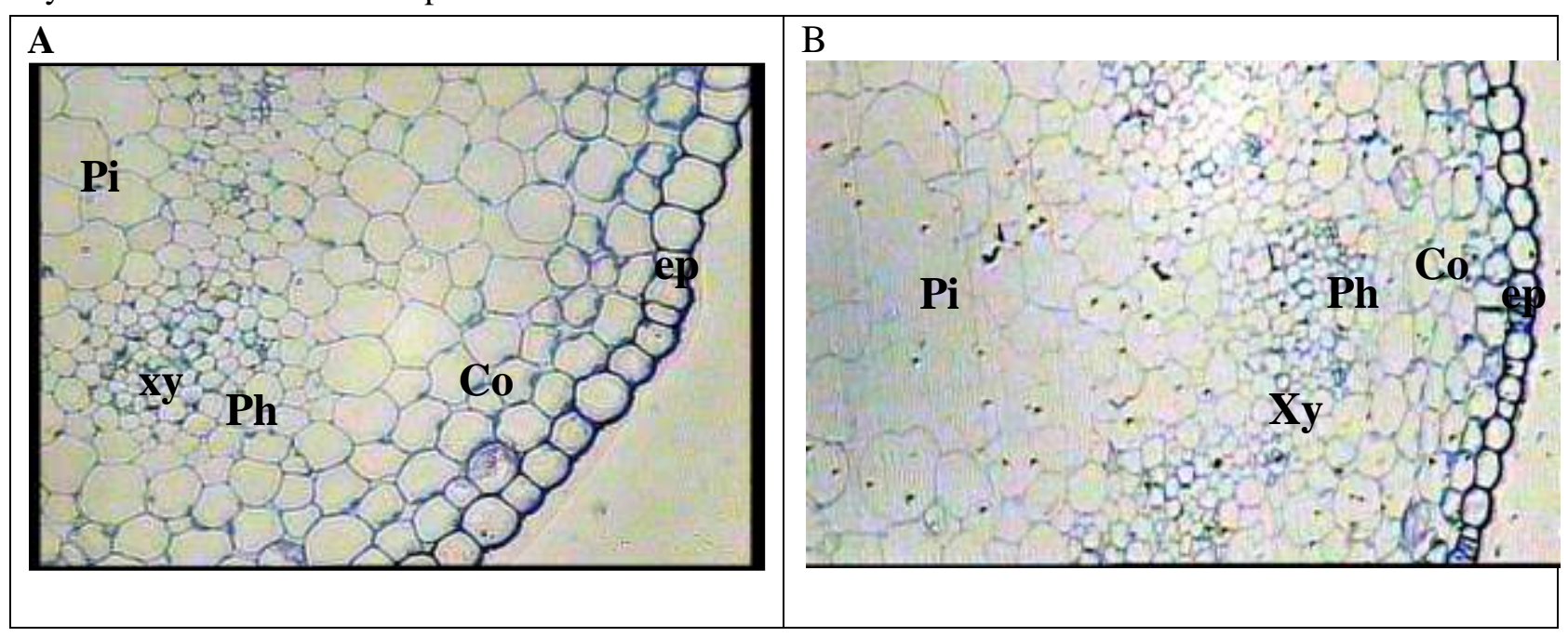

diam eters of the in vivo stem of both cultivars. The average pith diameter increased by 20.0 and $7 \%$ for Blanka and Giza 8, respectively. The pith cells of the in vitro stem increased in diameter by 11.6 and $25.0 \%$ as compared with the in vivo stems (Table 1 ).

The above mentioned results proved that the anatomical structure of the in vivo and in vitro stems are inversely distinctive. As, the in vitro stems were wider and maintained thicker basic epidermal cells as well as thick cortex and pith. This enlargement was mainly due to the increase in average cell size. In addition, the in vitro flax stems characterized by absence of supporting collenchyma and poor development of both sclernchyma tissues and vascular bundles. These results agree with those mentioned before by Sabh (1998) in clover Abd El-Zaher (2008) in jackfruit and Fauguel et al., (2008) in sun flower. Moreover, Hazarika (2005) reported that the stems

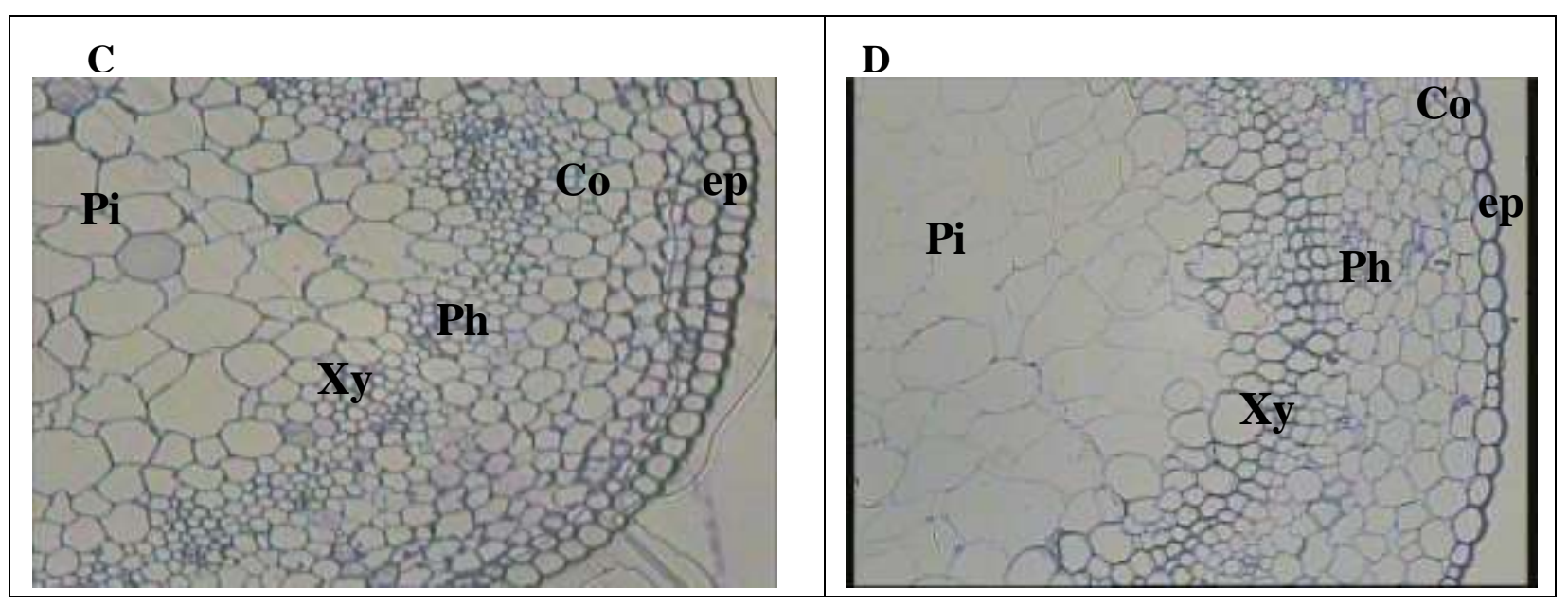

Fig. (3): Light micrographs of transverse sections of flax stems; flax cv. Blanka in vivo (A) and in vitro (B), flax cv. Giza 8 in vivo (C) and in vitro (D).

Details; Co: cortex, Ep: epidermis, Ph: phloem, Pi: pith, Xy: xylem. 
of red raspberry plantlets grown in vitro were most slender and had considerably less collenchyma and sclerenchyma supportive tissues than plants grown in the field.

\subsubsection{Leaf anatomical structure}

The anatomical structure of the leaves, either induced in vitro or grown in vivo was explored through the transverse section in the $2^{\text {nd }}$ leaf on the stem. Full microscopic measurements and counts are presented in (Table 2) and (Fig. 4). Generally, in vitro leaf was thinner as compared with the in vivo leaves as their thickness recorded 330 and $405 \mu$,respectively for Blanka, and 317 and $355 \mu$. for Giza 8. Thus, the average reductions in leaf thickness of the in vitro leaves were 11.0 and 9.0\% for Blanka and Giza 8, respectively.

The upper and lower epidermis of both in vivo and in vitro leaves of Blanka are characterized by uniform thin walled barrel shaped cells. While,leaf epidermis of the Giza 8 in vitro plants showed irregular thin walled cells. Moreover, the cuticle of both adaxial and abaxial side of the leaf of the in vivo plants was thicker as compared with the in vitro plants. The average thicknesses of the epidermis as shown in the transverse sections of Blanka were 35.5 and $37.5 \mu$ for the in vitro and in vivo leaves, respectively. The corresponding epidermis thickness for flax cv. Giza 8 were 22.5 and $30.5 \mu$, ( Table 2 and Fig. 4). It is evident that the mesophyll of the in vivo leaf showed well developed spongy mesophyll parenchyma cells with considerable amount of chloroplasts as compared with those of in vitro. Moreover, the mesophyll of in vitro leaf contained more loosely parenchyma cells with appreciably wide intercellular spaces . Little number of chloroplasts was observed in the in vitro spongy parenchyma which gave the leaves pale green color and negatively reflected on photosynthetic activity. The average mesophyll thicknesses were 285.0 and $225.0 \mu$ for the in vitro leaves of Blanka and Giza 8, respectively. The increase in leaf thickness found in the in vivo leaves was due to the increased number of spongy parenchyma cells rather than the enlargement in spongy cell size. On the contrary, the spongy parenchyma cells of in vitro leaves showed 17.2 and $12.6 \%$ increase in diameter than corresponding in vivo leaves of flax cvs. Blanka and Giza 8 , respectively. These values were reduced by 19.0 and $12.0 \%$ as compared with vessel diameters of the in vitro leaves for the two cultivars in the same order.

Regarding the midrib, it is obvious that, the in vivo leaf showed well differentiated midrib bundle. On reverse, the in vitro leaves showed reduced vascular bundles as compared with was in vivo. This reduction was reflected on the thickness of the midrib bundle and all tissues shared in their structure. The average thicknesses of the vascular bundles of the in vivo leaves were 175.0 and $152.0 \mu$ for Blanka and Giza 8, respectively. The corresponding thicknesses recorded for the in vitro leaves were 123.0 and $112 \mu$ for the two flax cultivars in the same order, Table (2) and Fig. (4). The phloem of the in vitro midrib was characterized by minute amounts of sieve elements mixed with extensive amounts of parenchyma cells. The phloem of in vivo leaves were 29.0 and $16.0 \%$ more than those of the in vitro leaves for flax cvs. Blanka and Giza 8, respectively. The xylem of the in vitro plants was also remarkably reduced as compared with the in vivo xylem. The average xylem thicknesses were 144.0 and $124.8 \mu$ for the in vivo as compared with 92.0 and $85.0 \mu$ for in vitro leaves. In addition, the average vessel diameters of the in vivo midrib were 29.1 and $27.7 \mu$ for the two studied flax cultivars Blanka and Giza 8, respectively. These

Table (2): Average measurements ( $\mu$ ) and counts of certain microscopical features in transverse sections of the leaves of the two flax cultivars Blanka and Giza8 grown in vitro and in vivo.

\begin{tabular}{|l|r|r|c|c|}
\hline \multirow{2}{*}{ Cultivars } & \multicolumn{2}{|c|}{ Blanka } & \multicolumn{2}{c|}{ Giza 8 } \\
\cline { 2 - 5 } & In vitro & \multicolumn{1}{|c|}{ In vivo } & In vitro & In vivo \\
\hline Leaf thickness & 330.0 & 405.0 & 317.0 & 355.0 \\
\hline Upper epidermis thickness & 35.5 & 37.5 & 22.5 & 30.5 \\
\hline Lower epidermis thickness & 198.5 & 164.2 & 221.0 & 183.2 \\
\hline Thickness of mesophyll & 285.0 & 300.0 & 225.0 & 375.0 \\
\hline Diameter of mesophyll cells & 25.7 & 20.2 & 20.1 & 17.8 \\
\hline Mid rib bundle thickness & 123.0 & 175.0 & 112.0 & 152.0 \\
\hline Xylem thickness & 92.0 & 144.0 & 85.0 & 124.8 \\
\hline Number of xylem rows & 4.0 & 6.0 & 4.0 & 6.0 \\
\hline Vessel diameter & 23.7 & 29.1 & 24.4 & 27.7 \\
\hline Phloem thickness & 58.2 & 44.9 & 51.6 & 48.4 \\
\hline
\end{tabular}




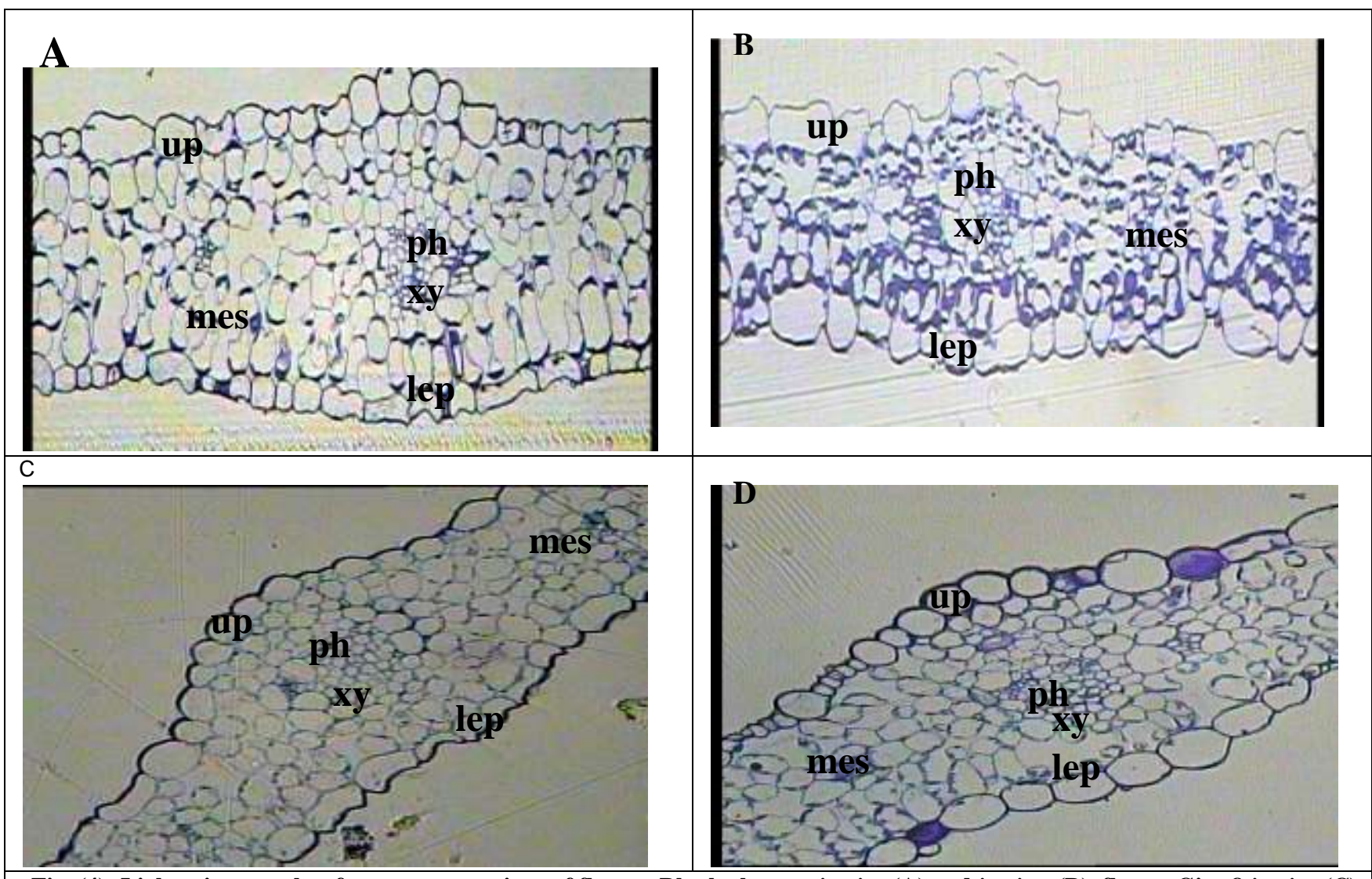

Fig. (4) :Light micrographs of transverse sections of flax cv. Blanka leaves; in vivo (A) and in vitro (B), flax cv Giza 8 in vivo (C) and in vitro (D).Details ; Lep: lower epidermis, Mes: mesophyll, Ph:phloem, Xy: xylem, Up:upper epidermis.

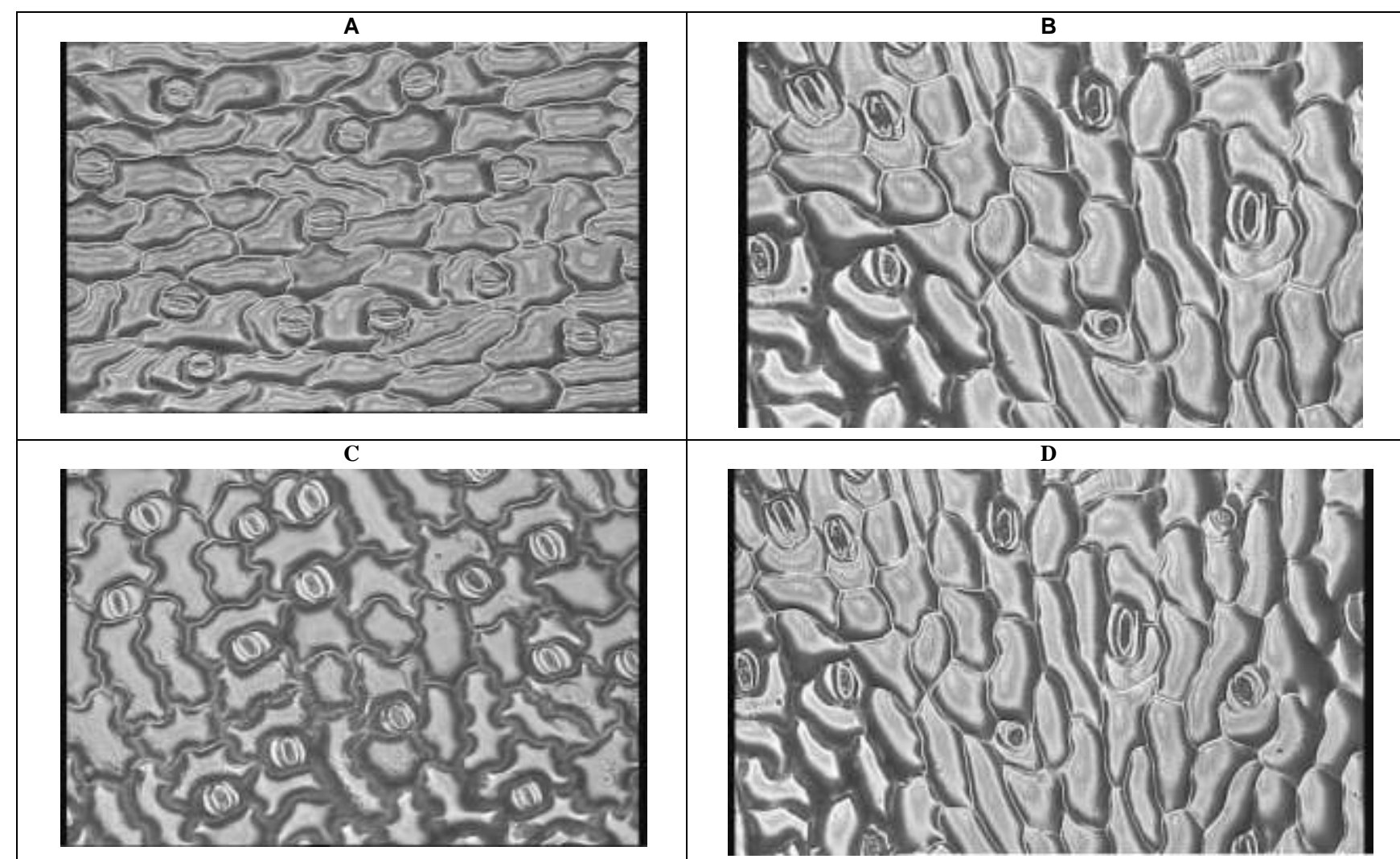

Fig. (5): Stomata of leaves surface of flax cv. Blanka; Lower surface in vivo (A), Lower surface in vitro (B), Upper surface in vivo (C), Upper surface in vitro (D). 
values were reduced by 19.0 and $12.0 \%$ as compared with vessel diameters of the in vitro leaves for the two cultivars in the same order.

The above mentioned results indicate that the in vitro flax shoots achieved thin leaves with poor differentiated epidermal, mesophyll and vascular tissues. This was previously reviewed by Hazarika (2005) who reported that, the poor mesophyll differentiation and weak vasculature of the leaves formed the in vitro render the plants highly susceptible to transplantation shock. Leaves of the plants grown in vitro were thinner and had a characteristically poor developed palisade layer with significant amount of mesophyll air space compared to the in vivo plants. Both micropropagated cauliflower (Grout and Aston, 1977) and sweet gum (Wetzstein and Sommer, 1982) plantlets failed to develop a clearly defined palisade layer in vitro.

Stomata on both lower and upper leaf surfaces of in vivo and in vitro leaves of. Blanka was further investigated. It is obvious that flax leaf lamina exhibited anomotetracytic stomata arrangement according to the subsidiary cells shape (Fig. 5). Also, it is evident that stomata were numerous in the lower leaf surface as compared with the upper leaf surface. On the lower leaf surface the stomata density varied between the in vivo and in vitro plants. The in vivo plants showed approximately $100 / \mathrm{mm}^{2}$, while the in vitro leaves showed $76 / \mathrm{mm}^{2}$. The reduction in stomata density of in vitro plants may be referred to the increase occurred in stomata size. As, the stomata size was increased by 44.0 and $18.0 \%$ for both stomata length and width, respectively. Stomata pore of in vitro plants was also increased in size comparing with the in vivo plants, (Fig 5). Same trend was obtained in the lower epidermis, where, the stomata density was greatly reduced in the in vitro plants. The average stomata density was $47 / \mathrm{mm}^{2}$ for in vitro leaves as compared with $82 / \mathrm{mm}^{2}$ for in vivo leaves.

The reduction in stomata density and size of in vitro plants was reported by many workers; among them Johansson et al. (1992), Radochova et al. (2000). On the contrary Hazariks (2005) reviewed that, there was no significant difference in stomatal frequency among in vitro, acclimatized and greenhouse-grown plants (Conner and Conner, 1984). But Zaid and Hughes (1995) reported that the stomatal frequency of greenhouse green leaves of date palm was significantly higher than the in vitro plantlets. It could be concluded from the comparative anatomy of in vitro and in vivo plants that, in vitro plants are very delicate owing to high humidity in the culture media, low light intensity and hetero or mixotrophic mode of nutrition. As a result, they lack the protective mechanisms like waxy cuticle, stomatal regulation, and poor development of photosynthetic tissues.

\section{REFERENCES}

Abd El-Zaher M.H. (2008). Studies on micro propagation of Jackfruit. 2-A comparative histological studies on in vitro and ex vitro plants of Jackfruit. World Journal of Agricultural Sciences, 4 (2): $255-262$

Bartosova G.H. (2006).Effect of growth regulators in direct regeneration. Hortic. Res., 32:565-571.

Belongova M.A. and Raldugina G.N., (2006). Shoot regeneration from cotyledon explant of fiber flax and their subsequent rooting, Russain Journal of Plant Physiology. 53(4): 555- 563.

Blinstrubiene A., Burbulis N. and Sliesaravicius A.(2004). Factors affecting callogenesis and organogenesis in tissue culture of oilseed flax (Linum usitatissimum L.). Journal of Genetics and Biotechnology . 2 (54):21-25.

Brainerd K.E. and Fuchigami L.H. (1981). Acclimatization of asceotically cultured plants under low relative humidity. J. Am. Soc. Hort. Sci. 106: 515-518.

Bretagne S., Kronesttedt-Robards E.C. and Robards A. W. (1994). Auxin- like activity of 1, 2 -benzisoxazole-3 alkanoic acids, Plant Cell Rep. 14: 120124.

Brudyni L., Lunia C., Tarrago I. , Sansberroi P., Dudit N., Gorizalezi A. and Morginski L. (2006). Direct shoot regeneration from leaf and internode explant of Aloysia polystachya (6Ris.) Mold. (Verbenaceae ) In Vitro Cell Dev. BiolPlant, 42: 335-239.

Burbulis N., Samaj J. and Sliesaravicius A. (2007). Gentic transformation of flax by agrobactrium of transformed shoots. Agri. Scientia; 55: 396-399.

Cointry E. L., Mroginski L. A. and Picardi L. A. ( 1993). Effect of growth regulators on in vitro shoot formation in three explant of flax (Linum usitatissimum L.). Agri. Scientia , 10: 39-43.

Conner L.N. and Conner A.J. (1984). Comparative water loss from leaves of Solanum laciniatum plants cultured in vitro and in vivo. Plant Sci. Lett.36, 241-246.

Cristina A., Gomes D.C. and Manuel F.F. (1997). Somatic embryogenesis, organogenesis 
and callus growth kinetics of flax. Plant cell. Tissue and Organ Culture, 47 (1): 55-60.

Dedicova B., Hricova A., Samaj J., Obert B., Bobak M. and Pretova A. ( 2000). Shoots and embryo-like structures regenerated from cultured flax (Linum usitatissimum L.) hypocotyls segments. Journal of Plant Physiology. 157(3):327-334.

Fauguel C.M., Vega T.A., Nestares G., Zorzoli R. and Picardi L.A.,( 2008). Anatomy of normal and hyperhydric sunflower shoots regenerated In vitro. HELIA, 31, Nr. 48, 17-26,

Friedt W. (1990). Biotechnology in breeding of industrial oil crops . Fat Sci. Technol. $90: 51-55$.

Green A.G. (1986). Amount genotype of flax (Linum usitatissimum L.) containing very low levels of linolnic acid in its seed oil. Can. J. Plant Sci.66:499-503.

Green, A.G. and Marshall, D.R. (1984). Isolation of induced mutants in linseed (Linum usitatissimum L.) having reduced linolonic content. Euphytica. 33:321328.

Grout B.W.W. and Aston M.J. (1977). Transplanting of cauliflower plants regenerated from meristem culture. I. Water loss and water transfer related to changes in leaf wax and to xylem regeneration. Hortic. Res. 1977. 17, 1-7.

Hazarika B.N. (2005). Morpho-physiological disorders in in vitro culture of plants. Journal-of-Plant-Physiology . 16(4): 315-320.

Johansson M., Kronesttedt-Robards E. and Robards C. W., (1992). Rose leaf structure in relation to different stages of micropropagation. Protoplasma 166: 165-176.

Keiko I., Hiroshi K. and Hiroshi H., (1997). Another evidence for inhibitory effect of auxin in adventitious bud formation of decapitated flax (Linum usitatissimum L.) seedling. Journal of Plant Physiology 110:387-392.

Lane W.D., (1979). Influence of growth regulators on root and shoot initiation from flax meristem-tips and hypocotyls in vitro. Physiologia Plantarum . 45:260-264.

Ling H.Q. and Bindihg H. (2006). Improvement of plant regeneration from linum . Journal of Plant Physiology. 139: 422-426.
Mahammad S. H., Tomikichi W. and Kazumi H. (1999). Anatomical changes during in vitro direct formation of shoot bud from root tips in garlic (Allium sativum L.) Plant Pood. Sci. 2 (2): 146-153.

Majada J. P., Fall M.A., Teado F. and SanchezTames R. (2002). Effect of natural ventilation on leaf ultrastructure of Dianthus caryophyllus L. cultured in vitro, In Vitro Cell Dev. Biol. Plant 38 : 272-278.

Marchuk W. N. and Raju M. V. (1978). Some anatomical changes in the cotyledonary node in relation to correlative inhibition of the lateral shoot growth in flax. Bot. Gaz. 139: 69-80.

Marin J.A., Gella K. and Herrero M. (1988). Stomatal structure and functioning as response to environmental changes in acclimatized micropropagated Рrunus cerasu L. Ann. Bot. 62 :663-670.

Mc Hughen A. and Schwartz M. (1984). A tissue culture derived salt tolerant linum of flax (Linum usitatissimum L.). Plant Physiol. 117: 109-117.

Murashige T. and Skoog F. (1962). A revised medium for rapid growth and bioassays with tobacco tissue culture. Phsiol. Plant. 15: 473-497.

Mustafa Y. and Murat O. ( 2002). A comparison of growth regulators for advection shoot regeneration from hypocotyls of flax (Linum usitatissimum L.) .J. of Food. 4: 171-174.

Netherland K.M., Umbach H. and Friedt W. (1988). Flax breeding and genetics in vivo and in vitro. Rostlinna-Vyroba. 58: 157-164.

Prece J.E. and Sutter E.G. (1991). Acclimatization of micropropagated plants to the green house and fieled. In: Debergh PC and Zimmerman RH (eds) Micropropagation Technology and Application Kiuwer Academic Publishers, Dordrecht ( 3):7191.

Radochova B., Vicankova A., Kutik J. and Ticha I. (2000). Leaf structure of tobacco in vitro grow plantlet as affected by saccharose and irradiance. Biological Plantarum. 43 (4): 633-636.

Rosna M.H. and Noorma W.H. (2008). Some morphological and anatomical studies of leaves and flowers of Marraya paniculata (Jack) Linn. in vivo and in vitro. Pakistan Journal of Biological 
Sciences 11 (7):1021-1026.

Rutkowska I. , Mankowska G. and Szopa J. (2003). Regeneration of flax (Linum usitatissimum L.) plants from anther culture and somatic tissue with increased resistance. Plant Cell Rep. 22:110-116.

Sabh A.Z. (1998). Study of Some Morphological and Chemical Aspects of In Vitro Plant Regeneration of Egyptian Clover (Trifoloium alexandrinum L.). Ph.D, Thesis. Faculty of Agriculture Cairo University.

Saravatiz C.H., Blazich F.A. and Amerson H.V. (1993). Histology of in vitro adventitious bud development on cotyledon and hypocotyls of Frazer Fir. J. Am. Soc. Hortic. Sci. 118:163-167.

Sutter E. and Langhans R.W. (1982). Formation of epicuticular wax and its effect on water loss in cabbage plants regeneration from shoot tip culture. Con. J. Bot. 60:2896-2902.
Tejklova E. (1992). Long-term in vitro shoot tip culture and plant regeneration in flax. Rostlinna-Vyroba. 38 (12): 1009-1022.

Wetzstein H.Y. and Sommer H.E. (1982). Leaf anatomy of tissue cultured Liquidambar styraciflua (Hamamelidaceae) during acclimatization. Am. J. Bot. 69, 15791586.

Zaid A. and Hughes H. (1995). A comparison of stomatal function and frequency of in vitro polyethylene glycol treated and greenhouse grown plants of date palm, Phoenix dactylifera L. Trop. Agric. (Trinidad) 72, 130-134.

Zhan X. C., Jones D. A. and Kerr A. (1989). In vitro plantlets formation in Linum marginale from cotyledons, hypocotyls, leaves,roots and protoplasts. Australian -Journal of Plant Physiology. 16(4): 315-320.

$$
\begin{aligned}
& \text { العوامل المؤثرة والخصائص التشريحية لتجدد النموات الخضرية معمليا لنبات الكتان } \\
& \text { عبد الحميد علي محم - عاطف زكريا سبع - زينب قاسم طه شعراوي } \\
& \text { قسم النبات الزر اعى ـ كلية الزر اعة - جامعة القاهرة- الجيزة- مصر }
\end{aligned}
$$

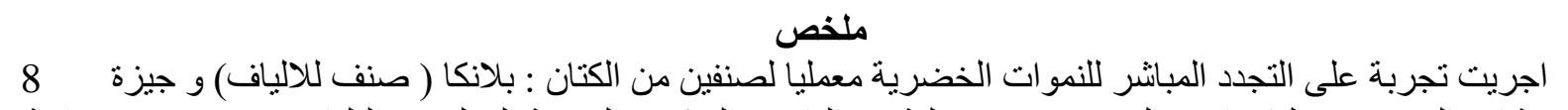

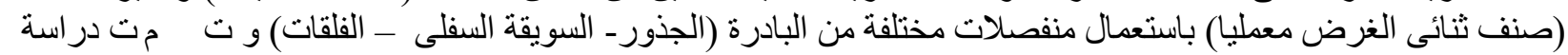

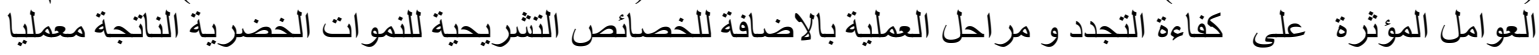

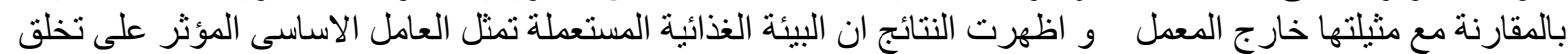

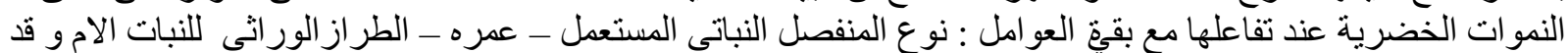

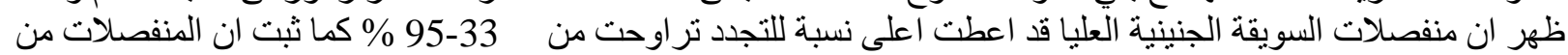

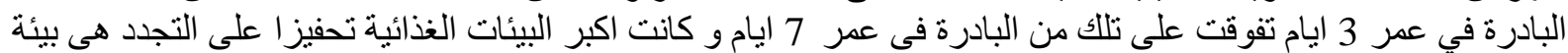

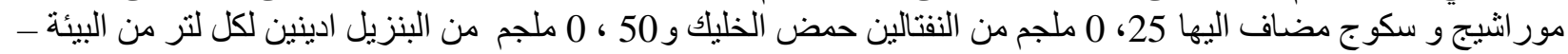

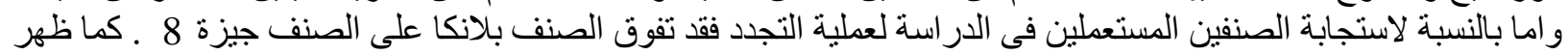

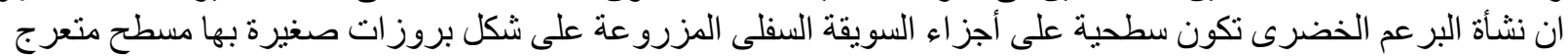

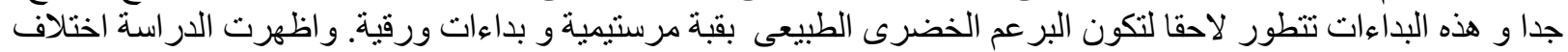

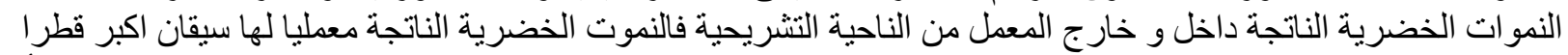

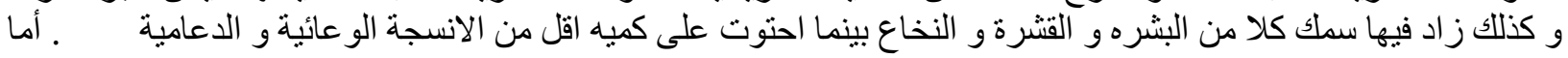

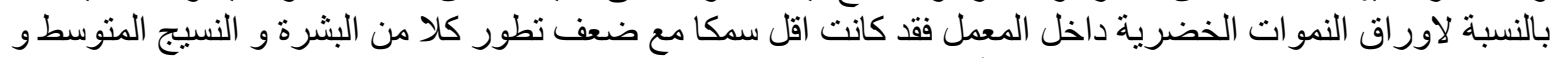

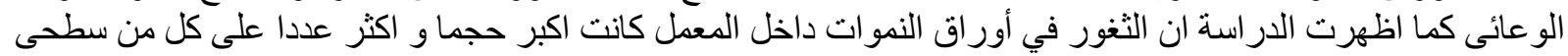
الورقة.

المجلة العلمية لكلية الزراعة - جامعة القاهرة - المجلد (61) العدد الثانى (إبريل 2010 ) : 162-172. 